Torsten Masson, Ortrud Leßmann*

\title{
Insecure Employment and Pro-Environmental Consumption: An empirical Analysis*
}

Pro-environmental consumption is one element of the behavioral change that is necessary to ensure sustainability. It is well known that consumption patterns differ according to socioeconomic status in general and that pro-environmental consumption behavior is affected by, among others, people's gender, education and current income. However, relatively few studies have tried to link pro-environmental consumption and socioeconomic characteristics beyond these well-known correlations. We aim to contribute to this literature by looking at the effects of the growing employment insecurity on pro-environmental consumption. Therefore we first review the literature on the effects of insecure employment and develop our hypotheses on the effects on purchase of organic food (as an example of pro-environmental consumption). Employing data from the German Socio-Economic Panel, we show that employment insecurity negatively affects frequency of organic food purchase, as well as perceived freedom of choice and attitudes toward organic food purchase. Our results thus hint at direct and indirect effects of insecurity on pro-environmental consumption behavior. The policy conclusion is that any strategy for sustainable development needs to include social policy in order to enable behavioral change.

Key words: insecure employment, organic food, pro-environmental behavior, consumption, Germany, German Socio-Economic Panel (JEL: D12, D31, D63, J28, Q01)

What's peculiar about uncertainty today is that it ... is woven into the everyday practices of a vigorous capitalism. Instability is meant to be normal, Schumpeter's entrepreneur served up as an ideal Everyman. ... "No long term" disorients action

* Torsten Masson, Department of Social Sciences, University of Applied Sciences Bielefeld, and Department of Environmental Politics, Helmholtz Centre for Environmental Research - UFZ, Germany; Ortrud Leßmann, Institute for Employment and Labour Relations, Helmut Schmidt University Hamburg, Germany and international research centre for social and ethical questions (ifz) Salzburg, Austria.

Correspondence concerning this article should be addressed to Torsten Masson, University of Applied Sciences Bielefeld, Interaktion 1, D-33619 Bielefeld, Germany. E-mail: Torsten.Masson@fh-bielefeld.de

** Acknowledgement: The research was carried out in the project soeb3 (Dritter Bericht zur sozioökonomischen Entwicklung in Deutschland) funded by the German Ministry for Education and Research (FKZ01UW11305I). The funding is gratefully acknowledged! The views expressed in the article are our own. We would like to thank Peter Bartelheimer, Wenzel Matiaske, the participants of the workshop on perspectives on sustainable consumption as well as two anonymous referees for their valuable comments.

Article received: October 19, 2015

Revised version accepted after double blind review: August 29, 2016

mrev, 28 (1) 2017, 1-3

DOI: $10.5771 / 0935-9915-2017-1-62$ 
over the long term, loosens bonds of trust and commitment, and divorces will from behavior. (Richard Sennett 1998)

\section{Introduction}

The transition to sustainable development is a collective task and behavioral change (i.e. more pro-environmental behavior) will presumably play a considerable part in it. However, behavior change takes place on the micro-level and people are not all in the same position for changing their behavior. This may seem trivial yet literature linking socioeconomic inequalities (beyond people's income and education) and pro-environmental consumption behavior is still relatively scarce. While it is still common to use income and education for determining the socioeconomic status of a person, the non-negligible increase of unemployment rates since the beginning of the 1970ies have brought the issue of secure employment - i.e. increase of non-standard (or precarious) employment - to the fore (Rodgers/Rodgers 1989). Not only poor, badly educated persons face these precarious employment conditions. They spread across social classes as determined by traditional social stratification theory. Hence, they challenge the idea of stable layers of society.

This paper aims to contribute to filling the gap by looking at the effects of employment insecurity on pro-environmental consumption as exemplified by purchase of organic food in Germany. ${ }^{1}$ Previous studies have found that consumers of organic food are often female, better educated and have a higher income (albeit the results for income and education are somewhat mixed; for reviews see Aertsens et al. 2009; Dimitri/Dettmann 2012; Hughner et al. 2007). However, to the best of our knowledge, no studies have yet investigated the effects of employment insecurity on organic food purchase. Linking insecure or precarious employment with pro-environmental consumption could provide further insights in processes underlying the behavior change necessary to foster a transition toward sustainability. The next section surveys the development towards growing employment insecurity and the literature on its measurement and finally the research on the impact on consumption patterns. The third section briefly introduces the aims and hypotheses of the present research and the fourth section the data base and measures. The fifth section presents the results concerning the - direct and indirect - effects of employment insecurity on purchasing behavior with regard to organic food as well as its effects on efficacy beliefs with regard to being able to influence the transition towards sustainability.

1 On average, production of organic food generates lower environmental impacts (e.g., energy use per product unit) than non-organic products (Tuomisto et al. 2012). 


\section{Insecure employment, precarity and its effects}

\section{The growing importance of job security}

Insecurity in employment started in the 1970ies in developed countries with nonnegligible rates of unemployment and rising numbers of non-standard employment (temporary employment etc.). By now, insecurity in employment is a global problem (International Labor Office 2015). Before the 1970ies, Fordism with mass production and mass consumption had enabled a rising living standard for large parts of society entailing employment as the key to social integration and standard occupation. This was accompanied by the standardization of life-course with the periods of education, training, employment, setting up a family and retirement (Kohli 1985). The standard had been ensured by a social security system that shifted responsibility from family and community to society at large. The success of this system was fuelled by high growth rates and full-employment (Castel 2003, Chapter 7) yet some inequality persisted (Atkinson 2015, pp. 18-19). The rise of unemployment starting in the 1970ies has triggered a rise in inequality and undermined the participation of those with several spells of unemployment or precarious work. Their impoverishment could initially be alleviated by social security payments and deviations from standard employment. Yet, since unemployment - while mainly hitting non- or little qualified workers - has befallen all layers of employees the upcoming insecurity has unsettled not only those who became unemployed, but has brought insecurity about labor market participation into the midst of society (Bourdieu 1999; Burzan 2014; Burzan/Berger 2010). Hence, "[t] he concept of precarious work goes beyond the form of employment to look at the range of factors that contribute to whether a particular form of employment exposes the worker to employment instability, a lack of legal and union protection, and social and economic vulnerability." (Rodgers/Rodgers 1989)

The phenomena triggered by these developments have been investigated as "job insecurity" (De Witte 2005; Sverke et al. 2006) as well as discussed in sociology under the terms "precarity" or "precariousness" (Castel 2003; Castel/Dörre 2009; Sennett 1998; Standing 2011, 2014). While the (mainly psychological) literature on job insecurity investigates its antecedents and consequences and disentangles the relation between "objective" and "subjective" job insecurity (De Witte/Näswall 2003), the sociological debate on "precarity" goes beyond this by looking not only at precarious jobs but at precarious conditions of life that may include other household or family members. It emphasizes that the responses to precarious employment range from fatalist downward drifting to active and (allegedly) willfully job-hopping (mainly in the "creative" sectors). Going further in the same vein, Sennett (1998) has described how precarity can lead to the "corrosion of character" in the sense of loosening the bonds of trust and commitment (e.g., to the community) due to the short-term perspective triggered by uncertain conditions of life. 
Previous studies have found job insecurity to be associated with a number of negative phenomena, including stress and work intensification (Burchell et al. 2002), mental health problems (Sverke et al. 2002; 2006), lower levels of organizational commitment (De Witte/Näswall 2003), and negative impacts on family relations (Hense 2015; Lozza et al. 2013). Castel (2003) explains the effects on family relations and social networks as indirect effects of the change in social security systems from family care to professional care financed collectively. However, the outstanding effect of precarity is that people in precarious conditions cannot make effective plans for the future (Bourdieu 1979). They miss agency in a fundamental way (Standing 2011).

\section{Measurement of job insecurity and precarious living conditions}

Empirical research has often aimed at measuring the extent of and increase in nonstandard employment (i.e. precarious employment) since the 1970s, including issues such as temporary agency work (Dütsch 2011; Nienhüser/Matiaske 2006), the spread of part-time work (Grözinger et al. 2010; Sopp/Wagner 2015) or increased labor-market flexibility (e.g., Burchell et al. 2002; Lehwess-Litzmann 2014; Struck 2009). Furthermore, a considerable body of qualitative research focused on coping behavior linked to non-standard employment (e.g., evaluation of frequent job changes) and its effects on social integration (Bescherer et al. 2008; Brinkmann et al. 2006; Dörre 2008; Gallie/Paugam 2002).

Research on precariousness (in Germany) so far has mainly relied on objective indicators of precarity (Hense 2015), whereas the concept of job insecurity has mostly been conceptualized "as a perceptual phenomenon" (Jacobson 1991, p. 31). Contrasting objective and subjective indicators of job insecurity, De Witte and Näswall (2003) show that the overlap between the two is limited: Not all persons with temporary employment feel that their job is insecure. Their employment history (e.g., number of unemployment spells) as well as expectations about the ease of getting a new job or about job loss matter as well (Hense 2015, Chapter 2.2). A long-term perspective is important to distinguish between insecurity that relates to a specific job (i.e. job insecurity) and insecurity concerning employment as a whole (i.e. employment insecurity measured by number of unemployment spells) since frequent job changes need not lead to frequent or long unemployment spells. The employment history also defines much of what a person becomes entitled to in modern welfare states and the resulting vulnerability of the person. Thus, employment insecurity - as we will call it - induces precarious living conditions if neither the social 
network (e.g., other household members) nor the wealth and social security entitlements accumulated in life course can compensate for the reduced income. ${ }^{2}$

\section{Employment insecurity and ecologically sustainable consumption}

Although consumption is seen as an important aspect in environmental sociology (Gross/Heinrichs 2010), the number of studies investigating insecure employment and sustainable consumption is limited (Kraemer 2011). In Germany, the classification of society into "Sinus-milieus" (based on Bourdieu's work on life-styles) has been used to link social status and sustainable consumption (Blättel-Mink 2010, Kleinhückelkotten/Wegner 2008; Wippermann/Hübsch 2007). However, the socalled "precarious milieu", sometimes also called "consumption-materialists", is characterized by the desire to keep up with the middle class by compensating social deprivation with consumption (Kleinhückelkotten/Wegner 2008). The classification into milieus hence follows mostly values and attitudes in addition to income but does not cover issues such as employment insecurity or overall precarious conditions of life.

Research on the impact of employment insecurity on general consumption levels is also small. Results show that precautionary savings - especially with regard to consumption of durables - are a frequent response to employment insecurity (Benito 2005; Bowman 2013). However, the effect is shown to depend on the availability of assets and other sources of income, indicating that precautionary savings may be motivated by anticipated future income constraints. Going beyond this by including subjective job insecurity Lozza et al. (2013) show that subjective insecurity is more important than the objective current employment condition in orienting daily consumption. This is in line with the assumption that job insecurity can be compensated by other factors (e.g., income provided by other household members) and need not lead to precarity of living conditions. Lozza et al. (2013) further show a negative impact of job insecurity on long-term projects such as buying a home, marrying or having a child.

The latter is highly relevant for linking pro-environmental consumption and employment insecurity: As stated above, precarity is characterized by the inability to make plans for the future thus inducing a short-term perspective. In contrast, sustainability is characterized by the long-term perspective of thinking about the wellbeing of future generations. This gives rise to the expectation that employment insecurity (given missing sources for compensation of income loss) will conflict with pro-environmental consumption. Adding to that, if Standing's (2011) statement of

2 The latter effect may also depend on age: For young people the accumulated wealth and entitlements are lower, but the probability of finding a new job is higher. The probability for older people to find a new job and to fill the gap in wealth and social security contributions is much lower. Accordingly, older employees perceive higher job insecurity when being on temporary employment than younger ones (Lozza et al., 2013, p. 95). 
lacking agency is correct, people in precarious living conditions may not only have a short-term orientation, but question their ability of bringing about change in a more fundamental way. Since they miss control over the simpler task of earning their living, they will presumably lose faith in having an impact on the future of the earth.

\section{The Present Research}

The present research aims to investigate the links between insecure employment and (relatively) costly pro-environmental consumption behavior (i.e. purchase of organic food). For empirical analysis, we use data from the Innovation Sample of the German Socio-Economic Panel (GSOEP-IS), that covers questions about purchase of organic food. ${ }^{3}$ Based on our theorizing above, employment insecurity should lead individuals to buy less organic food (i.e. pay a premium for pro-environmental consumption), due to potential future income constraints (or higher income insecurity) and more short-term thinking. That is, we expect employment insecurity to be accompanied by less frequent organic food purchase (Hypothesis 1a) as well as lower intentions to buy such food in the future (Hypothesis 1b), after controlling for the effects of other individual- and household-level characteristics like environmental concern, level of education or current household income. We furthermore assume that the effects of employment insecurity on organic food purchase are mediated by perceived freedom of choice and attitudes linked to organic food. More specifically, we expect that employment insecurity negatively affects organic food purchase through perceived freedom of choice (Hypothesis 2) as well as attitudes (Hypothesis 3) - two well established predictors of food purchase (Leßmann/ Masson 2015). Increased employment insecurity may exert a negative effect on perceived freedom of choice due to potential future income constraints (or higher income insecurity) linked to employment insecurity. Similarly, attitude changes may reflect "sour grapes" (i.e. "I can't have it, so I don't like it"), that is a strategy to balance the lower perceived freedom to buy organic food with one's ambitions to do so.

Finally, we expect that persistent insecure employment would lead individuals to question their ability of bringing about change, be it on the personal level or the societal level. We therefore expect employment insecurity to negatively influence efficacy beliefs (self- and consumer efficacy) to contribute to sustainable development, both directly (Hypothesis 4) as well as through perceived (personal) competence and autonomy. In other words, frequent experience of unemployment should lead individuals to question their ability to behave in a self-determined manner

3 The German Socio-Economic Panel (GSOEP) is a 30-years longitudinal survey of approximately 11,000 private households in Germany. Variables include household composition, employment, occupation, earnings, health, and life satisfaction indicators (see Richter/Schupp, 2012 for a further description of the GSOEP-IS). 
(competent, autonomous) and to live up to own and others' expectations. We therefore expected employment insecurity to negatively affect people's feelings of personal competence and autonomy, which, in turn, should be positively associated with efficacy beliefs to contribute to sustainable development (Hypothesis 5).

\section{Data and measures}

Data for this study were retrieved from the 2012 wave of the GSOEP-IS. The basic sample for organic food purchase contained 700 individuals $\left(56.9 \%\right.$ female; $\mathrm{M}_{\text {age }}=$ 51.02 years, $\mathrm{SD}_{\text {age }}=18.53$ years). Due to our focus on employment insecurity, we restricted the sample to respondents aged between 25 and 65. In Germany, working age population usually ranges from 15 to 65 years. However, due to our measure of employment insecurity (number of unemployment spells last 10 years), we only included respondents aged between 25 and 65 . The final sample contained 455 respondents $\left(56.9 \%\right.$ female, $\mathrm{M}_{\text {age }}=47.76$ years, $\mathrm{SD}_{\text {age }}=11.62$ years $)$. All data used are cross-sectional. We employed multiple linear regression analysis as well as mediation analysis to investigate our assumptions.

Table 1 presents the measures of the model variables. Item selection was limited by data availability in the GSOEP-IS. However, the items selected are based on measures commonly applied in environmental behavior research (Bamberg et al. 2003; Dunlop et al. 2000; Kaiser/Gutscher 2003; Manning 2009) as well as in research on insecure employment (Benito 2005, Hense 2015, de Witte 2005), and on basic psychological needs (Deci/Ryan 2000) respectively. The GSOEP-IS provided different possible indicators of employment insecurity, including number of unemployment spells in the last 10 years, number of job changes in the last 10 years, fixedterm contracts, and temporary agency work. However, the sample for organic food purchase contained less than 50 respondents with fixed-term contracts and/or temporary agency work, therefore seriously limiting their statistical power. Furthermore, number of job changes does not indicate the employment status whereas the number of unemployment spells in the last 10 years captures a history of frequent unemployment spells between jobs. Unlike the other indicators it is not restricted to a single job and does not count those who work in a sector characterized by short term contracts. Employment insecurity was thus assessed with number of unemployment spells in the last 10 years. Due to high skewness employment insecurity 
was re-coded into three categories (see Table 1$).{ }^{4}$ Education (low, middle, high) was assessed following the International Standard Classification of Education (ISCED) and equivalized disposable income was calculated based on the modified OECD equivalence scale (Hagenaars et al. 1994).

\section{Results}

The effects of a history of insecure employment on purchase of organic food: an exploratory analysis of self-reported purchase behavior, perceived freedom of choice and attitudes toward organic food purchase

\section{a) Direct effects of employment insecurity on organic food purchase}

In a first block of analyses, we investigated possible direct effects of insecure employment on organic food purchase. We thus submitted (self-reported) frequency of organic food purchase to multiple regression analysis including employment insecurity (i.e. number of unemployment spells in the last 10 years), environmental concern as well as a number of other covariates (education, equivalized income etc.). The results are presented in Table 2. In line with Hypothesis 1a, frequency of organic food purchase was negatively affected by employment insecurity $(\beta=-.11, p<$. $05) .{ }^{5}$ Bootstrapping $(5,000$ bootstrap samples) supported this result (bootstrap $p=$. 02). That is, the more often respondents had been unemployed during the last 10 years, the less frequently they tended to purchase organic food. To test the reliability of this finding, we reran the analysis replacing frequency of organic food purchase with (future) intention to buy organic food. Consistent with the previous results, employment insecurity led to lower intentions to purchase organic food $(\beta=-.15, p$ $<.01)$. Obviously, insecure employment negatively affected participants' tendency as well as their intentions to buy organic food, thus providing evidence for Hypotheses $1 \mathrm{a}$ and $1 \mathrm{~b}$. Importantly, these effects remained stable after inclusion of environmental concern, equivalized income and other socioeconomic characteristics in the analysis. Results are thus not simply attributable to less pro-environmental attitude or less (current) household income among those with high employment insecurity. Rather, persons who have repeatedly experienced unemployment and who

4 To validate our measure of employment insecurity, we investigated the links between number of unemployment spells in the last 10 years (i.e. employment insecurity) on the one side and perceived personal employment and income constraints (e.g., perceived constraints due to lack of work, lack of money, lack of education) as well as worries about own future ( $1=$ "I don't worry at all" to 3 "I worry to a great extent") on the other side, after controlling for a number of individual- and household-level characteristics (education, equivalized income, household size, current unemployment status etc.). Number of unemployment spells was positively correlated with perceived personal constraints $(B=.20, p<.01)$ and with worries about own future $(B=.10, p=.02)$, thus supporting the assumption that frequent experiences of past unemployment significantly increased perceived constraints and worries.

5 Two outliers with studentized residuals exceeding $|2.5|$ were excluded for this analysis. Keeping the outliers in the analysis changed the significance of employment insecurity to $p=.055$. 
Table 1: Model variables

\begin{tabular}{|c|c|c|}
\hline Variable & Question & Scale \\
\hline \multicolumn{3}{|c|}{ Organic food purchase } \\
\hline $\begin{array}{l}\text { Intention to purchase organic } \\
\text { food ( } 1 \text { item) }\end{array}$ & $\begin{array}{l}\text { "How often do you intend to pur- } \\
\text { chase organic food in the future?" }\end{array}$ & $\begin{array}{l}1 \text { "never" - } 5 \text { "very of- } \\
\text { ten" }\end{array}$ \\
\hline $\begin{array}{l}\text { Self-reported frequency of or- } \\
\text { ganic food purchase (1 item) }\end{array}$ & $\begin{array}{l}\text { "How often have you bought organic } \\
\text { food within the last } 3 \text { months?" }\end{array}$ & $\begin{array}{l}1 \text { "never" - } 5 \text { "very of- } \\
\text { ten" }\end{array}$ \\
\hline $\begin{array}{l}\text { Attitude toward organic food } \\
\text { purchase }(2 \text { items, } r(447)=.76)\end{array}$ & $\begin{array}{l}\text { "Purchasing organic food is a good } \\
\text { thing to do." } \\
\text { "Purchasing organic food is pleasant." }\end{array}$ & $\begin{array}{l}1 \text { "do not agree" - } 5 \\
\text { "totally agree" }\end{array}$ \\
\hline $\begin{array}{l}\text { Perceived freedom of choice to } \\
\text { buy organic food (1 item) }\end{array}$ & $\begin{array}{l}\text { "How much freedom do you have to } \\
\text { purchase organic food?" }\end{array}$ & $\begin{array}{l}1 \text { "very little" - } 5 \text { "very } \\
\text { much" }\end{array}$ \\
\hline $\begin{array}{l}\text { Environmental concern (15 } \\
\text { items, Cronbach's } \alpha=.74 \text { ) }\end{array}$ & $\begin{array}{l}\text { Example items: "We are approaching } \\
\text { the limit of the number of people the } \\
\text { Earth can support."; "Plants and ani- } \\
\text { mals have as much right as humans } \\
\text { to exist." }\end{array}$ & $\begin{array}{l}1 \text { "do not agree" - } 5 \\
\text { "totally agree" }\end{array}$ \\
\hline \multicolumn{3}{|c|}{ Insecure employment } \\
\hline $\begin{array}{l}\text { Employment insecurity (1 } \\
\text { item) }\end{array}$ & $\begin{array}{l}\text { "How often have you been unem- } \\
\text { ployed during the last } 10 \text { years" }\end{array}$ & $\begin{array}{l}0=\text { never been unem- } \\
\text { ployed, } 1=1 \text { unemploy- } \\
\text { ment spell, } 2=2 \text { un- } \\
\text { employment spells, } 3= \\
3 \text { or more unemploy- } \\
\text { ment spells }\end{array}$ \\
\hline \multicolumn{3}{|c|}{ Others } \\
\hline $\begin{array}{l}\text { Efficacy beliefs to contribute to } \\
\text { sustainable development ( } 2 \\
\text { items, } \mathrm{r}(438)=.70 \text { ) }\end{array}$ & $\begin{array}{l}\text { "How much can the following actors } \\
\text { contribute to sustainable develop- } \\
\text { ment ... [myself; consumers]?" }\end{array}$ & $\begin{array}{l}1 \text { "very little" - } 10 \text { "very } \\
\text { much" }\end{array}$ \\
\hline $\begin{array}{l}\text { Personal competence and au- } \\
\text { tonomy ( } 6 \text { items, Cronbach's } \alpha \\
=.76)\end{array}$ & $\begin{array}{l}\text { Example items: "Most days I feel a } \\
\text { sense of accomplishment from what I } \\
\text { do."; "People tell me I am good at } \\
\text { what I do" }\end{array}$ & $\begin{array}{l}1 \text { "do not agree" - } 7 \text { "to- } \\
\text { tally agree" }\end{array}$ \\
\hline
\end{tabular}

thus feel less secure about their job opportunities and about their future income are less inclined to buy organic food. Furthermore, corroborating past studies (Aertsens et al.; Dimitri/Dettmann 2012; Hughner et al. 2007), our findings indicated that equalized income and environmental concern were both positively correlated with frequency of organic food purchase $(p s<.01-.05)$. That is, participants living in relatively well-off households and those who described themselves as pro-environmentalists tended to buy organic food more frequently. Furthermore, better (vs. worse) educated respondents, women (vs. men) and persons living in single (vs. non-single) households reported to purchase organic food more often (all $p s<.01$ $-.05)$. 
Table 2: Regression of self-reported frequency of organic food purchase on employment insecurity and socioeconomic characteristics

\begin{tabular}{|c|c|c|c|c|c|}
\hline & $\beta$ & & $R^{2}$ & $\operatorname{adj} . R^{2}$ & $F$ \\
\hline & & & .18 & .16 & $11.87^{* * *}$ \\
\hline $\operatorname{Sex}(0=$ male, $1=$ female $)$ & .21 & $4.54^{* * *}$ & & & \\
\hline Age & -.11 & $-2.24^{* *}$ & & & \\
\hline Equivalized household income & .17 & $3.04^{* * *}$ & & & \\
\hline Single household ( $0=$ no, $1=$ yes $)$ & .12 & $2.49^{* *}$ & & & \\
\hline $\begin{array}{l}\text { Education ( } 1=\text { low, } 2=\text { middle, } 3= \\
\text { high) }\end{array}$ & .16 & $3.00^{* * *}$ & & & \\
\hline Environmental concern & .10 & $2.20^{* *}$ & & & \\
\hline Employment insecurity & -.11 & $-2.17^{* *}$ & & & \\
\hline
\end{tabular}

Note. ${ }^{*} p<.10 ;{ }^{* *} p<.05 ;{ }^{* * *} p<.01$

b) Indirect effects through perceived freedom of choice and attitudes linked to organic food

In a second block of analyses, we investigated possible indirect effects of employment insecurity on organic food purchase through perceived freedom of choice and attitudes linked to organic food respectively. ${ }^{6}$ To test whether the relation between employment insecurity and organic food purchase was jointly mediated by perceived freedom of choice and attitudes, we conducted multiple mediation analysis, employing Preacher's and Haye's (2008) SPSS macro "INDIRECT". 7 We also entered age, sex, education, equivalized income, environmental concern, and the single household dummy as covariates in the analysis (for both mediators as well as the dependent variable). The multiple mediation model (without covariates) is depicted in Figure 1.

Consistent with our expectations, there was a significant joint indirect effect of employment insecurity on organic food purchase through both mediators $(I E=-.12$, $S E=.04)$, with a bias corrected $95 \%$ confidence interval $(\mathrm{CI})$ of -.20 to $-.04 .^{8}$ Inspection of the model paths indicated that greater employment insecurity led to lower perceived freedom of choice (Hypothesis 2) and to lower attitudes (Hypothesis 3 ), although the path to perceived freedom of choice was only marginally significant $(p=.058)$. In other words, employment insecurity negatively affected organic food purchase through attitudes and perceived freedom of choice. Further analysis of the two separate indirect effects showed that attitudes mediated the effects of em-

6 An indirect (or mediated) effect equals the difference between the total and the direct effects of the independent variable (i.e. employment insecurity) on the criterion variable (i.e. frequency of organic food purchase). A variable that mediates the effect of the independent variable on the criterion variable is called mediator (i.e. attitudes and perceived freedom of choice).

7 Joint mediation analysis is superior to testing separate mediation models for each mediator, especially if the mediators are highly correlated (Preacher/Hayes, 2008).

8 The total and direct effects of employment insecurity on self-reported frequency of organic food purchase were $-.14, \mathrm{p}<.05$, and $-.02, \mathrm{p}=.60$, respectively. 
Figure 1 Multiple mediation of the insecurity-food purchase relation through perceived freedom and attitudes (standardized path coefficients).

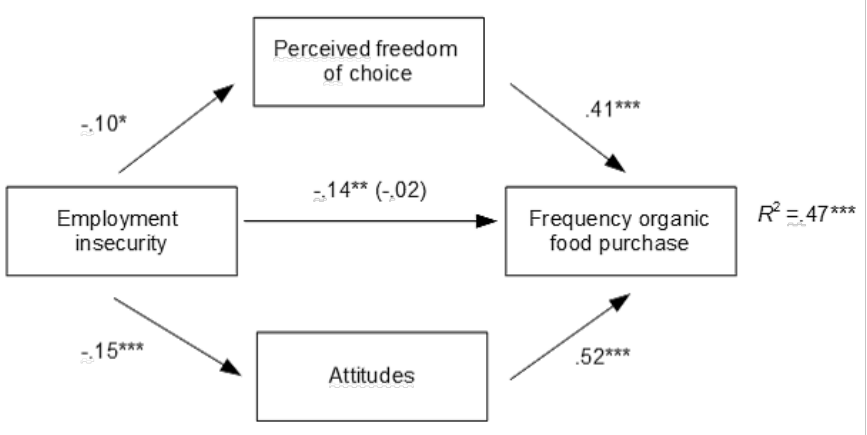

Note. ${ }^{*} p<.10 ;{ }^{* *} p<.05 ;{ }^{* * *} p<.01$; covariates: age, sex, education, equivalized income, environmental concern, single household dummy

Table 3: Bootstrapped point estimates and confidence intervals for the specific and total indirect effects of employment insecurity on frequency of organic food purchase, and contrast between indirect effects

\begin{tabular}{|c|c|c|c|c|}
\hline & \multirow[t]{2}{*}{ Point estimate } & \multirow[t]{2}{*}{ SE } & \multicolumn{2}{|c|}{$\mathrm{BC} 95 \% \mathrm{Cl}$} \\
\hline & & & Lower & Upper \\
\hline \multicolumn{5}{|l|}{ Indirect effects } \\
\hline Perceived freedom of choice & -0.04 & 0.02 & -0.09 & 4 \\
\hline Attitude & -0.08 & 0.03 & -0.13 & -0.03 \\
\hline Total & -0.12 & 0.04 & -0.20 & -0.04 \\
\hline \multicolumn{5}{|l|}{ Contrast } \\
\hline $\begin{array}{l}\text { Perceived freedom of choice } \\
\text { vs. attitude }\end{array}$ & 0.04 & 0.03 & -0.02 & 0.10 \\
\hline
\end{tabular}

Note. $\mathrm{BC} \mathrm{Cl}=$ bias corrected confidence intervals; 1,000 bootstrap samples.

ployment insecurity on organic food purchase (see Table 3). The 95\% CI of perceived freedom of choice contained zero, indicating that the indirect effect through perceived freedom of choice was marginally significant $(p=.067)$. However, examination of the contrast of both indirect effects (see Table 3) revealed that the indirect effect through attitudes was not significantly larger than the indirect effect through perceived freedom of choice (i.e. 95\% CI of contrast contained zero). Replacing frequency of organic food purchase with intentions to buy organic food yielded comparable findings. Results showed a significant joint indirect effect through perceived freedom of choice and attitudes ( $I E=-.13, S E=.05$; 95\% CI -.23 to -.05). However, the indirect effect through attitudes was significantly greater than through perceived freedom of choice. 
In line with Hypotheses 2 and 3, both attitudes and (to a lesser extent) perceived freedom of choice fully mediated the impact of employment insecurity on frequency of organic food purchase as well as on purchase intentions. That is, frequent experience of unemployment was shown to diminish perceived freedom of choice to buy organic food and to result in less favorable attitudes - which, in turn, predicted food purchase behavior. Notably, the effects remained stable after inclusion of socioeconomic characteristics (income, education etc.) and environmental concern in the mediation analysis. Obviously, mere consideration of direct effects will underestimate the complex links between insecurity and food purchase that are cognitively mediated by less favorable evaluations linked to organic food.

\section{The effects of insecure employment on efficacy beliefs to contribute to sustainable development}

\section{a) Direct effects of employment insecurity on efficacy beliefs}

In a first block of analyses, we investigated possible direct effects of insecure employment on efficacy beliefs to contribute to sustainable development. To test our assumption, we submitted efficacy beliefs to multiple regression analysis including employment insecurity, environmental concern and other socioeconomic covariates (age, sex, income, education etc.). Results showed no significant main effect of employment insecurity on efficacy beliefs $(p=.60)$, thus not supporting Hypothesis $4 .^{9}$

\section{b) Indirect effects through personal competence and autonomy}

In a second block of analyses, we investigated possible indirect effects of employment insecurity on efficacy beliefs through perceived (personal) competence and autonomy (Hypothesis 5). To test Hypothesis 5, we conducted simple mediation analysis, entering age, sex, education, equivalized income, the single household dummy, and environmental concern as covariates. The mediation model is depicted in Figure 2.

Consistent with our expectations, there was a significant indirect effect of employment insecurity on efficacy beliefs linked to sustainability through personal competence and autonomy $(I E=-.04, S E=.02 ; 95 \% \mathrm{CI}-.8$ to -.01$)$. Inspection of the model paths indicated that greater employment insecurity led to lower perceived competence and autonomy $(p<.01)$, which, in turn, was positively correlated with efficacy beliefs $(p<.01)$. Supporting Hypothesis 5 , employment insecurity negatively affected respondents' perceived ability to contribute to sustainability through changes in (perceived) personal competence and autonomy. Notably, personal com-

9 Exploratory regression analysis with interaction tests indicated that employment insecurity led to lower efficacy beliefs for older respondents, but not for younger participants. As a possible explanation, we reasoned that older (vs. younger) participants often have less opportunities to find a new job. For older people, frequent experiences of unemployment therefore may translate more strongly into feelings of low personal efficacy and control. 
Figure 2: Simple mediation of the insecurity-efficacy beliefs relation through personal competence and autonomy (standardized path coefficients).

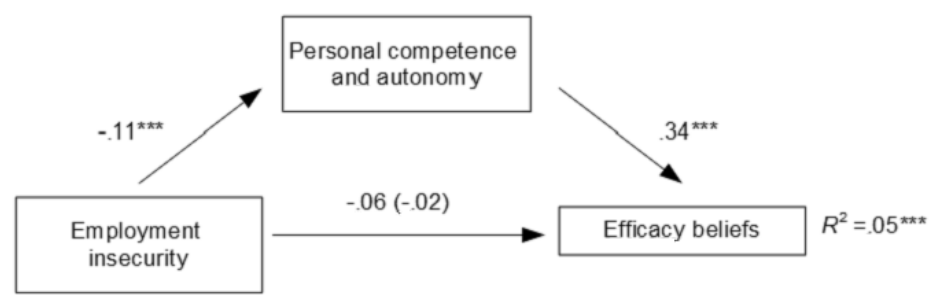

Note. ${ }^{*} p<.10 ;{ }^{* *} p<.05 ;{ }^{* * *} p<.01$; covariates: age, sex, education, equivalized income, environmental concern, single household dummy

petence and autonomy fully mediated the effects of employment insecurity on efficacy to contribute to sustainable development. This indicates that the links between insecure employment and efficacy beliefs were contingent on changes in people's perception of themselves as competent and autonomous actors.

\section{Conclusion: Pro-environmental consumption needs social policy}

This paper aimed at investigating the conditions for (financially demanding) proenvironmental consumption behavior as a major factor in the transition to sustainability. In particular, it looks at the influence of employment insecurity on the purchase of organic food. Employment insecurity is regarded by sociologists but also by the policy analysts of the ILO (2015) as a phenomenon of growing importance. It impairs people's ability to make plans for the future (and to have control over their lives), and thus induces a short-term perspective. In contrast, sustainability is characterized by a long-term perspective that implies thinking about the well-being of future generations. Hence, sustainable development needs a time horizon that is hard to sustain for people perceiving high employment insecurity as indicated by the studies of its impact on the consumption of durables (Benito 2005) or longterm projects (Lozza et al. 2013).

Focusing on the influence of employment insecurity on purchase of organic food we found evidence for direct negative effects of insecurity on self-reported purchasing behavior and future purchase intentions (Hypotheses 1a and 1b). Furthermore, our findings also indicate that the negative effects of employment insecurity were contingent on changes of perceived freedom of choice and attitudes towards buying organic food (i.e. indirect effects), thus supporting Hypotheses 2 and 3. Finally, high levels of employment insecurity also lowered people's beliefs to effectively contribute to sustainable development in general, albeit these effects were mediated by perceived personal competence and autonomy. That is, frequent experience of unemployment was accompanied by lower perceived competence and autonomy, 
which, in turn, was positively correlated with sustainability efficacy beliefs (Hypothesis 5). Notably, all effects remained stable after inclusion of socioeconomic characteristics in the analysis (e.g., income, education, sex, age).

In sum, results hint at complex links between employment insecurity and pro-environmental consumption. Less stable income may motivate individuals to spend less money (i.e. precautionary savings) and thus may reduce overall consumption levels (i.e. less total resource use; Kraemer 2011). Simultaneously, insecure employment also decreases people's perceived opportunities to engage in financially demanding pro-environmental consumption behavior (e.g., organic food purchase), potentially limiting the achievement of sustainability. However complex the links are, the results show that awareness-rising - as frequently requested - is not sufficient to bolster costly pro-environmental consumption. Our findings indicate that pro-environmental consumption may not only fail due to lack of concern with the environment but also because individuals face economic insecurity that impedes them from acting on their beliefs and even undermines their self-confidence. Put somewhat provocative: pro-environmental consumption needs social policy that enhances people's opportunities to act on their pro-environmental beliefs. Being able to make plans for the future is a precondition of this and it requires a mixture of measures ranging from regulation concerning work contracts over creating an environment that enables people to care for environmental issues. Admittedly, these measures can only complement economic policies that strengthen pro-environmental production and supply, but a pure strategy of fostering pro-environmental consumption will fail due to lacking social policy.

The results also confirm the cogency of going beyond socioeconomic factors such as income, gender, and current labor-market inclusion as predictors of pro-environmental consumption: employment insecurity was found to affect organic food purchase after controlling for the effects of other factors. That is, the negative correlation between insecurity and food purchase is not simply attributable to e.g. changes in household income linked to frequent unemployment. While it is not surprising that low income households tend to buy less organic food, our results show that frequent experience of unemployment explained additional variance in purchase behavior, perceived freedom of choice and attitudes. Given the increase of insecure employment (ILO 2015), our findings thus call for future research that explicitly links employment insecurity and pro-environmental consumption choices.

Of course, our analyses are somewhat exploratory since the sample was relatively small and only considered one (relatively costly) pro-environmental consumption behavior. It remains to be shown that the findings are valid for larger samples and other financially demanding behaviors. That is, future research may jointly take into account aggregated consumption measures (e.g., general consumption levels) as well as qualitative aspects (e.g., share of organic food) to investigate the effects of employment insecurity on pro-environmental consumption in more detail. Further- 
more, data restrictions did not allow us to employ different measures of employment insecurity. Despite the by now long-standing research, measurement of precarious employment is not straightforward due to the aspect of time incorporated and its subjective character. Future research may therefore employ alternative measures of insecure employment, including fixed term contracts or number of job changes as well as measures of subjective employment insecurity to test the reliability of our findings. Furthermore, future studies may test whether the effects of employment insecurity on pro-environmental consumption are mediated by perceived responsibility to fight environmental issues (i.e. high levels of insecurity may lead to less perceived responsibility).

\section{References}

Aertsens, J., Verbeke, W., Mondelaers, K., van Huylenbroeck, G. (2009). Personal determinants of organic food consumption: a review. British Food Journal, 111, 1140-1167. http:// dx.doi.org/10.1108/00070700910992961

Aiken, L.S., West, S.G. (1991): Multiple Regression: Testing and interpreting interactions. Newbury Park, CA: Sage.

Atkinson, A. B. (2015). Inequality: what can be done?. Cambridge, Massachusetts: Harvard University Press.

Benito, A. (2005). Does job insecurity affect household consumption? Oxford Economic Papers, 58(1), 157-181. http://doi.org/10.1093/oep/gpi041

Bamberg, S., Ajzen, I., Schmidt, P. (2003). Choice of travel mode in the theory of planned behavior: The roles of past behavior, habit, and reasoned action. Basic and Applied Social Psychology, 25, 175-188.

Bescherer, P., Röbenack, S., Schierhorn, K. (2008). Nach Hartz IV: Erwerbsorientierung von Arbeitslosen (After the so-called ,Hartz'-reforms: employment orientation of unemployed). In K. Belwe (Ed.), Armut - Prekarität - Abstieg (pp. 19-24). Bonn: bpb. Retrieved from http:// www.bpb.de/shop/zeitschriften/apuz/31016/abstieg-prekaritaet-ausgrenzung

Blättel-Mink, B. (2010). Konsum und Nachhaltigkeit-ein Widerspruch? (Consumption and Sustainability - contradicting each other?) Forschung Frankfurt, 03/2010, 26-30.

Bourdieu, P. (1999) Job insecurity is everywhere now. Acts of Resistance: Against the Tyranny of the Market. New York: New Press.

Bourdieu, P. (1979). Algeria 1960: The Disenchantment of the World: The Sense of Honour: The Kabyle House or the World Reversed: Essays. Studies in Modern Capitalism. Cambridge [Eng.] New York: Cambridge University Press.

Bowman, J. (2013). How does job insecurity affect household consumption in Australia? University of New South Wales. Retrieved from https://www.business.unsw.edu.au/About-Site/Schools-Site/ Economics-Site/Documents/Joel_Ashley_Bowman.pdf

Brinkmann, U., Dörre, K., Röbenack, S., Kraemer, K., Speidel, F. (2006). Prekäre Arbeit: Ursachen, Ausmaß, soziale Folgen und subjektive Verarbeitungsformen unsicherer Beschäftigungsverhältnisse. (Precarious Work: Causes, Extent, Social Consequences and Subjective Coping with insecure employment) edited by Friedrich-Ebert-Stiftung and Gesprächskreis Migration und Integration (Friedrich-Ebert-Stiftung). Bonn: Friedrich-Ebert-Stiftung. 
Burchell, B., Ladipo, D., Wilkinson, F. (Eds.). (2002). Job insecurity and work intensification. London; New York: Routledge.

Burzan, N. (2014). Die Mitte der Gesellschaft: sicherer als erwartet? (The Middle Class: more secure than expected?) Weinheim: Beltz Juventa.

Burzan, N., Berger, P. A. (Eds.). (2010). Dynamiken (in) der gesellschaftlichen Mitte. (Middle Class Dynamics) Wiesbaden: VS Verlag für Sozialwissenschaften.

Castel, R.. 2003. From Manual Workers to Wage Laborers: Transformation of the Social Question. New Brunswick, N.J: Transaction Publishers.

Castel, R., Dörre, K. (Eds.). (2009). Prekarität, Abstieg, Ausgrenzung: die soziale Frage am Beginn des 21. Jahrhunderts. (Precarity, Descent, Exclusion: The social question at the beginning of $21^{\text {st }}$ century) Frankfurt am Main: Campus.

De Witte, H. (2005). Job insecurity: Review of the international literature on definitions, prevalence, antecedents and consequences. SA Journal of Industrial Psychology, 31(4). http://doi.org/ 10.4102/sajip.v 31i4.200

De Witte, H., Näswall, K. (2003). Objective vs subjective job insecurity: consequences of temporary work for job satisfaction and organizational commitment in four European countries. Economic and Industrial Democracy, 24(2), 149-188.

Deci, E. L., Ryan, R. M. (2000). The "what" and "why" of goal pursuits: Human needs and the selfdetermination of behavior. Psychological Inquiry, 11, 227-268.

Dimitri, C., Dettmann, R.L. (2012). Organic food consumers: what do we really know about them? British Food Journal, 114, 1157-1183. DOI 10.1108/00070701211252101

Dörre, K. (2008). Armut, Abstieg, Unischerheit.(Poverty, Descent, Insecurity) In K. Belwe (Ed.), Armut - Prekarität - Abstieg (pp. 3-6). Bonn: bpb. Retrieved from http://www.bpb.de/shop/ zeitschriften/apuz/31016/abstieg-prekaritaet-ausgrenzung

Dunlap, R.E., van Liere, K.D., Mertig, A. G., Jones, R.E. (2000). Measuring endorsement of the new eco-logical paradigm: A revised NEP scale. Journal of Social Issues, 56, 425-442.

Dütsch, M. (2011). Wie prekär ist Zeitarbeit? Eine Analyse mit dem Matching-Ansatz. (Is temporary agency work precarious? Analysis employing the matching approach) Zeitschrift für ArbeitsmarktForschung, 43(4), 299-318. http://doi.org/10.1007/s12651-011-0060-z

Gallie, D., Paugam, S. (2002). "Social Precarity and Social Integration.” Report for the European Commission Directorate General Employment Eurobarometer 56.1. Brüssel. http:// ec.europa.eu/public_opinion/archives/ebs/ebs_162_en.pdf.

Gross, M., Heinrichs, H. (Eds.). (2010). Environmental Sociology: European Perspectives and Interdisciplinary Challenges. Dodrecht: Springer.

Grözinger, G., Matiaske, W., Tobsch, V. (2010). Employee-friendly labour time: a key element to a sustainable pattern of production and consumption. International Journal of Public Policy, 5(4), 357-372.

Hagenaars, A., de Vos, K. Zaidi, M.A. (1994). Poverty Statistics in the Late 1980s: Research Based on Micro-data, Office for Official Publications of the European Communities. Luxembourg.

Hense, A. (2015). Wahrnehmung der eigenen Prekarität. Grundlagen einer Theorie zur sozialen Erklärung von Ungleichheitswahrnehmungen. (Perception of one's precarity. Foundations of a theory for explaining perceptions of inequality) Bielefeld, Bielfeld. 
Hughner, R.S., McDonagh, P., Prothero, A., Shultz, C.J., Stanton, J. (2007). Who are organic food consumers? A compilation and review of why people purchase organic food. Journal of Coumser Behaviour, 6, 94-110. DOI: 10.1002/cb.210

International Labor Office. (2015). World employment and social outlook 2015. [Place of publication not identified]: Brookings Institution Pr.

Jacobson, D. (1991). The conceptual approach to job insecurity. In J. Hartley (Ed.), Job insecurity: coping with jobs at risk (pp. 23-39). London; Newbury Park: Sage Publications.

Kaiser, F., Gutscher, H. (2003). The Proposition of a General Version of the Theory of Planned Behavior: Predicting Ecological Behavior. Journal of Applied Social Psychology, 33, 586-603.

Kohli, M. (1985) Die Institutionalisierung des Lebenslaufs: Historische Befunde und theoretische Argumente. (Institutionalization of Life Course: Historical evidence and theoretical arguments) Kölner Zeitschrift für Soziologie und Sozialpsychologie, 37, 1-29.

Kleinhückelkotten, S., Wegner, E. (2008). Nachhaltigkeit verbreiten. (Spreading sustainability) Ökologisches Wirtschaften-Fachzeitschrift, 23(2). Retrieved from http://oekologischeswirtschaften.de/index.php/oew/article/viewArticle/566

Kraemer, K. (2011). Prekärer Wohlstand und nachhaltiger Konsum. (Precarious welfare and sustainable consumption) Österreichische Zeitschrift für Soziologie, 36(2), 35-54. http://doi.org/ $10.1007 / \mathrm{s} 11614-011-0032-0$

Lehwess-Litzmann, R. (2014). Capability as a yardstick for flexicurity: using the Senian paradigm to evaluate a European policy agenda. Göttingen: Universitätsverlag Göttingen.

Lessmann, O., Masson, T. (2015). Sustainable consumption in capability perspective: Operationalization and empirical illustration. Journal of Behavioral and Experimental Economics, 57, 64-72. http://doi:10.1016/j.socec.2015.04.001

Lozza, E., Libreri, C., Bosio, A. C. (2013). Temporary employment, job insecurity and their extraorganizational outcomes. Economic and Industrial Democracy, 34(1), 89-105. http://doi.org/ $10.1177 / 0143831 X 12436617$

Manning, M. (2009). The effects of subjective norms on behaviour in the theory of planned behaviour: A meta-analysis. British Journal of Social Psychology, 48, 649-705.

Nienhüser, W., Matiaske, W. (2006). Effects of the "principle of non-discrimination" on temporary agency work: compensation and working conditions of temporary agency workers in 15 European countries. Industrial Relations Journal, 37(1), 64-77. http://doi.org/10.1111/j. 1468-2338.2006.00390.x

Preacher, K. J., Hayes, A. F. (2008). Asymptotic and resampling strategies for assessing and comparing indirect effects in multiple mediator models. Behavior Research Methods, 40, 879-891.

Richter, D.; Schupp, J. (2012). SOEP Innovation Sample (SOEP-IS) - Description, Structure and Documentation. SOEPpapers on Multidisciplinary Panel Data Research, 463, Berlin.

Rodgers, G., Rodgers, J. (Eds.). (1989). Precarious jobs in labour market regulation: the growth of atypical employment in Western Europe. Geneva, Switzerland: [Brussels]: International Institute for Labour Studies; Free University of Brussels.

Sennett, R. (1998). The corrosion of character: the personal consequences of work in the new capitalism (1st ed). New York: Norton.

Sopp, P., Wagner, A. (2015). Long-term Trends in Working Time Preferences of Men and Women in Germany and the Probability of their Realisation - the Role of Agreed Working Time. IWPLMS, Athen. 
Standing, G. (2011). The Precariat. Bloomsbury Academic. Retrieved from http://www.bloomsburycollections.com/book/the-precariat-the-new-dangerous-class

Standing, G. (2014). A precariat charter: from denizens to citizens. London; New York: Bloomsbury.

Struck, O. (2009). »Abstiegssorgen der Mitte« Flexibilität benötigt Sicherheiten. (The worries of the middle class - flexibility requires securities) In R. Castel \& K. Dörre (Eds.), Prekarität, Abstieg, Ausgrenzung: die soziale Frage am Beginn des 21. Jahrhunderts (pp. 269-282). Frankfurt am Main: Campus.

Sverke, M., Hellgren, J., Näswall, K. (2002). No security: A meta-analysis and review of job insecurity and its consequences. Journal of Occupational Health Psychology, 7(3), 242-264. http:// doi.org/10.1037/1076-8998.7.3.242

Sverke, M., Hellgren, J., Näswall, K. (2006). Job insecurity: A literature review. Arbetslivsinstitutet. Retrieved from http://nile.lub.lu.se/arbarch/saltsa/2006/wlr2006_01.pdf

Tuomisto, H.L., Hodge, I.D., Riordan, D.W., Macdonald, D.W, (2012). Does organic farming reduce environmental impacts? A meta-analysis of European research. Journal of Environmental Management, 112, 309-320. http://dx.doi.org/10.1016/j.jenvman.2012.08.018

Wippermann, C., Hübsch, H. (2007). Bio-Käufer in den Sinus-Mileius. (Buyers of organic food in Sinus-milieu-strata) Bio-Fach, Bio-Verlag, Heidelberg/Nürnberg. 